\title{
Close calls
}

$\mathrm{U}$ ntil Apr. 1, one might have thought that things had quieted down around here. However, just an hour ago, and for more than the thousandth time over the past 8 years, 3 missiles were launched from Gaza into southern Israel. Were they aimed at an army base, or at a strategic military installation? No. They were lobbed across the border as if a child were tossing a water balloon. However, these rockets are packed with rather more dangerous material: high explosives, together with nails and screws meant to maximize damage to human tissue. Unfortunately, as physicians in Israel we have far too much clinical experience with such weapons. Fortunately, although clearly aimed indiscriminately at Israel's civilian population, this time they happened to miss.

But not always. For example, in January during the Gaza conflict, 9-year-old Orel was not so lucky. I remember the event all too well. While teaching medical students, an air raid siren went off. We all scuttled toward inadequate cover - doctors, students, patients and their families packed together in the inner corridor all hoping the missile would strike elsewhere. Almost immediately we heard 3 consecutive booms, the third very close by. From the last rocket the young lad took fragments to the brain.

How did we organize ourselves as the missiles rained down? First, the hospital administration moved quickly into emergency gear. Unfortunately, we in Israel are quite used to military threats. All holiday leave was cancelled, and to add to the pressure many doctors were called up to the military reserves. Given the nature of army service, these are usually physicians between the ages of 30 and 50, exactly those with the heaviest clinical load. We all pitched in.

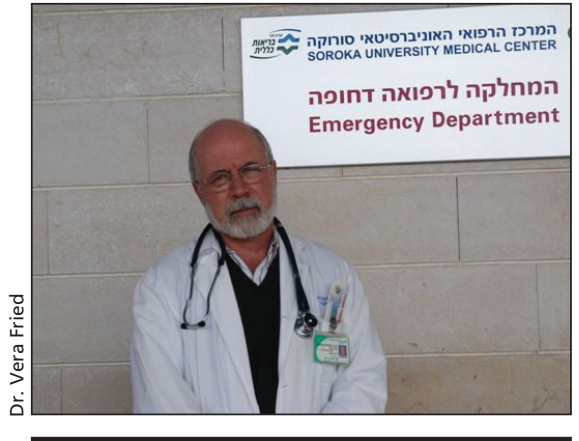

Dr. Mark Clarfield stands outside the emergency room at Soroka Hospital.

An interesting challenge involved retaining hospital workers with young children because all schools had been closed. In quick order we organized a daycare centre with easy access to bomb shelters. In this way, while still worried about their kids, working parents were able to come to work.

Not that there weren't several close calls. As a result, the other health facility in the south, a 300-bed hospital only 6 miles from Gaza almost closed completely for the duration. My own Soroka Hospital (at 1100 beds, the largest in the south) came under direct fire. During one attack, I was alone in my office when the siren went off. As instructed, I ran toward the "secure" (ha!) area, put my hands over my head and awaited my fate. A few seconds later I heard and felt a tremendous crash immediately outside the ward. A Grad missile had struck just on the other side of the hospital perimeter. I don't even want to think of the damage it might have done had it landed a few metres closer.

As doctors, most of our conversations dealt with how we were to get our patients safely through the day. Oddly enough, none of us actually expressed our own fears openly. It was, I guess, a question of pride and in a way involved our sense of professionalism. As in all difficult clinical situations, the first thing a good doctor learns to suppress is an expression of his own fears - Aequanimitas à la Osler and all that.

But one thing that came up repeatedly was our sense from the international media that many commentators were concentrating exclusively on the damage done to Gaza.

Many chose to ignore the fact that Hamas had broken the ceasefire and started the latest chapter of this tragic conflict. As well, many but not all correspondents seemed to miss the point that in the fog of war, some of our shells would inevitably go astray and unintentionally hit innocent civilians. Even worse, they ignored the clear fact that each and every Hamas missile was aimed indiscriminately at our civilian population.

Still, as medical professionals, our remit was health, not politics and we did our best under difficult circumstances. Obviously, the solution to this conflict lies not in medicine but rather in the convoluted world of diplomacy. Only when peace breaks out will doctors on both sides be able to concentrate on our prime mission: to look after patients without the fear of missiles flying in either direction. - A. Mark Clarfield, $\mathrm{MD}$, Beersheva, Israel

DOI:10.1503/cmaj.090822

CMAJ invites contributions to "Dispatches from the medical front," in which physicians and other health care providers offer eyewitness glimpses of medical frontiers, whether defined by location or intervention. Submissions, which must run a maximum 700 words, should be forwarded to: wayne.kondro@cmaj.ca. 